\title{
PERBANDINGAN HUKUM TERKAIT PEMBENTUKAN PASAL PENGHINAAN TERHADAP PERADILAN, PERZINAHAN, DAN SANTET DALAM RKUHP INDONESIA
}

\author{
Farrel Alanda Fitrah \\ Mahasiswa Fakultas Hukum, Universitas Padjadjaran, Bandung \\ Email Korespondensi: farrel.alanda2001@gmail.com
}

Tanggal Penyerahan: 21 Januari 2021

Tanggal Publikasi: 14 Februari 2021

\begin{abstract}
Abstrak. Penelitian ini bertujuan untuk menganalisis aspek perbandingan hukum terkait pembentukan pasal penghinaan terhadap peradilan, perzinahan, dan santet dalam RKUHP Indonesia. Penelitian ini menggunakan metode penelitian yuridis normatif dengan spesifikasi bersifat deskriptif. Adapun metode analisis yang digunakan dalam penelitian ini adalah analisis perbandingan hukum. Perbandingan hukum dilakukan untuk mengetahui persamaan dan perbedaan unsur dari setiap sistem hukum, sehingga dapat menjadi alternatif dalam menyikapi persoalan-persoalan tertentu. Hasil penelitian menunjukkan bahwa Indonesia menganut civil law system sebagai warisan dari Belanda. Akan tetapi, tidak ada lagi negara yang murni menganut civil law system atau common law system. Perpaduan antara civil law system dan common law system di Indonesia disertai pula dengan perpaduan antara unsur hukum agama dan hukum adat. Hal ini dapat diketahui dari aspek perbandingan hukum terkait pembentukan pasal penghinaan terhadap peradilan, perzinahan, dan santet dalam RKUHP Indonesia. Tindak pidana penghinaan terhadap peradilan atau contempt of court dirumuskan dalam Pasal 302-325 RKUHP, dimana muatan dari Pasal tersebut merupakan perpaduan dari common law system. Tindak pidana perzinahan dirumuskan dalam Pasal 418 RKUHP, dimana muatan dari Pasal tersebut merupakan perpaduan dari hukum agama yang ditransformasikan ke dalam sistem hukum Indonesia yang menganut civil law system. Tindak pidana delik santet dirumuskan dalam Pasal 252 RKUHP, dimana muatan dari Pasal tersebut merupakan perpaduan antara sistem hukum adat dengan sistem hukum agama yang berusaha diterapkan ke dalam sistem hukum Indonesia. Olehnya itu, disarankan agar peran perbandingan hukum dalam menelaah proses pembaharuan hukum harus terus dilakukan, sehingga sistem hukum di Indonesia terus bergerak ke arah yang lebih baik.
\end{abstract}

Kata Kunci: Contempt of Court; Pembentukan Pasal; Perbandingan Hukum; Perzinahan; RKUHP; Santet.

artikel dengan akses terbuka dibawah lisensi CC BY -4.0 


\section{PENDAHULUAN}

Perbandingan hukum atau comparative law adalah metode untuk membandingkan berbagai ilmu hukum yang ada. Dalam praktiknya, terjadi perbedaan pendapat di antara para ahli mengenai perbandingan hukum merupakan sebuah metode atau sebuah ilmu. Berikut uraian definisi perbandingan hukum sebagai ilmu pengetahuan oleh para ahli, antara lain yaitu:

Menurut Barda Nawawi Arief: ${ }^{1}$

"Perbandingan hukum merupakan ilmu pengetahuan yang secara sistematis mempelajari hukum (pidana) dari dua atau lebih sistem hukum dengan menggunakan metode perbandingan."

Menurut Romli Atmasasmita: ${ }^{2}$

"Perbandingan hukum merupakan ilmu pengetahuan yang secara sistematis mempelajari persamaan dan perbedaan antara sistem-sistem hukum asing yang diperbandingkan"

Menurut W. L. G. Lemaire: ${ }^{3}$

"Perbandingan hukum merupakan cabang ilmu pengetahuan (yang juga menggunakan metode perbandingan) yang mempunyai lingkup (isi) dari kaidah-kaidah hukum, persamaan dan perbedaannya, sebab-sebabnya, dan dasar-dasar kemasyarakatannya."

Dari ketiga definisi di atas, dapat dipahami bahwa perbandingan hukum sebagai ilmu pengetahuan tetap menggunakan metode perbandingan untuk membandingkan berbagai macam hukum yang ada. Adapun definisi perbandingan hukum sebagai metode oleh para ahli, antara lain yaitu:

Menurut Sunarjati Hartono: ${ }^{4}$

"Perbandingan hukum merupakan suatu metode penyelidikan dan bukan dari cabang ilmu hukum, sebagaimana yang sering diasumsikan oleh beberapa orang. Metode digunakan untuk membandingkan sebuah lembaga hukum (legal Institution) di berbagai negara, dengan memiliki kesamaan sistem hukum. Setelah melakukan perbandingan hukum, maka secara bersamaan dapat diketahui unsur-unsur persamaan dan perbedaan perbedaannya."

Menurut Rudolf B. Schlesinger: ${ }^{5}$

"Perbandingan hukum merupakan suatu metode penyelidikan untuk memperoleh pengetahuan yang lebih dalam tentang bahan hukum tertentu. Perbandingan hukum bukanlah seperangkat aturan dan asas-asas hukum, bukan pula suatu cabang hukum, melainkan suatu teknik untuk menyikapi unsur hukum asing dari suatu masalah hukum."

\footnotetext{
${ }^{1}$ Barda Nawawi Arief. (1990). Perbandingan Hukum Pidana. Jakarta: Rajawali Pers, hlm. 4.

${ }^{2}$ Romli Atmasasmita. (1996). Perbandingan Hukum Pidana. Bandung: CV. Mandar Maju, hlm. 6.

${ }^{3}$ Barda Nawawi Arief. (1990). Loc. Cit.

${ }^{4}$ Sunarjati Hartono. (1986). Kapita Selekta Perbandingan Hukum. Bandung: PT. Alumni, hlm. 1.

${ }^{5}$ Barda Nawawi Arief. (1990). Loc. Cit.
} 
Dari uraian di atas, baik definisi perbandingan hukum sebagai ilmu pengetahuan maupun sebagai metode, dapat ditarik kesimpulan bahwa inti dari perbandingan hukum adalah suatu kegiatan yang dilakukan untuk membandingkan sistem-sistem hukum yang terdapat di berbagai negara. Adapun tujuan praktis dari perbandingan hukum, antara lain yaitu: ${ }^{6}$

1. Untuk kepentingan pembentukan peraturan perundang-undangan.

a. membantu dalam membentuk peraturan perundang-undangan yang baru atau perubahannya.

b. persiapan dalam menyusun peraturan perundang-undangan yang bersifat uniform.

c. penelitian pendahuluan pada receptie peraturan perundang-undangan asing.

2. Untuk kepentingan peradilan, dimana secara umum dapat mempengaruhi penerapan prinsip peradilan.

3. Untuk kepentingan perjanjian internasional.

4. Untuk kepentingan menerjemahkan peraturan perundang-undangan.

Hukum sebagai objek dalam perbandingan hukum terdiri dari berbagai macam sistem hukum. Para ahli hukum mengklasifikasikan sistem hukum berdasarkan kriteriakriteria tertentu, misalnya dari aspek historis dan yuridis. Selain itu, belum adanya kriteria yang pasti dan bersifat universal dalam mengklasifikasikan berbagai macam sistem hukum, maka setiap ahli memiliki klasifikasi tersendiri dalam menguraikan pemahaman-pemahamannya terkait sistem hukum. Menurut John Henry Merryman \& Rogelio Pérez-Perdomo, sistem hukum berdasarkan tradisi hukum terdiri dari tiga kategori utama, yaitu: ${ }^{7}$

1. Common Law;

2. Civil Law; dan

3. Socialist Law.

Menurut René David \& John E. C. Brierley, sistem hukum berdasarkan konsep dari keluarga hukum (the idea of a family of laws) terdiri dari empat kategori utama, yaitu: ${ }^{8}$

1. The Romano-Germanic Family;

2. The Common Law Family;

3. The Family of Socialist Law; dan

4. The Traditional Religious Law (conceptions of law and the social order).

${ }^{6}$ Ach. Dlofirul Anam. (2015). "Studi Komparasi antara Konsep Hak Jaminan Resi Gudang Menurut Undang-Undang No. 9 Tahun 2011 dengan Konsep Rahn (Gadai) dalam Hukum Islam". Skripsi. Fakultas Syariah, Universitas Islam Negeri Maulana Malik Ibrahim, Malang, hlm 26.

${ }^{7}$ John Henry Merryman \& Rogelio Pérez-Perdomo. (2007). The Civil Law Tradition: An Introduction to the Legal Systems of Europe and Latin America. California: Stanford University Press, hlm. 1-2.

${ }^{8}$ René David \& John E. C. Brierley. (1978). Major Legal Systems in the World Today: An Introduction to the Comparative Study of Law. New York: Free Press, hlm. 21-29. 
Menurut Marc Ancel, sistem hukum berdasarkan sistemnya terdiri dari lima kategori utama, yaitu: ${ }^{9}$

1. The Systems of Continental and Latin America (Civil Law System);

2. The Anglo-American/Anglo-Saxon System (Common Law System);

3. The System of the Middle East;

4. The System of the Far East;

5. The System of the Socialist Countries.

Perbandingan hukum merupakan kegiatan yang lazim dilakukan di setiap negara termasuk Indonesia, guna untuk memperbaharui peraturan perundang-undangan agar selaras dengan perkembangan zaman. Pembentukan peraturan perundangundangan merupakan kegiatan yang berlangsung secara terus menerus, terutama dalam cabang kekuasaan legislatif yang memiliki fungsi legislasi. Berdasarkan daftar Program Legislasi Nasional Rancangan (Prolegnas) Rancangan Undang-Undang (RUU) Tahun 2020-2024, terdapat 248 RUU yang harus disahkan. ${ }^{10}$ Hal ini membuktikan bahwa proses pembentukan dan perubahan peraturan perundang-undangan sedang serta terus berlangsung dari waktu ke waktu.

Dewan Perwakilan Rakyat (DPR) sebagai positive legislator yaitu lembaga yang memiliki kewenangan untuk melakukan pembentukan dan perubahan UndangUndang (UU), tentunya menggunakan perbandingan hukum untuk menilai bahwa UU tersebut masih konteks dengan zaman sekarang atau perlu di ubah atau dicabut dan dibentuk UU baru. Kegiatan seperti kunjungan ke luar negeri yang dilakukan oleh anggota DPR juga merupakan rangkaian dari melakukan perbandingan hukum antara sistem hukum di Indonesia dengan sistem hukum negara tersebut.

Salah satu peraturan perundang-undangan yang menjadi sorotan dari banyak ahli hukum adalah Undang-Undang Republik Indonesia Nomor 1 Tahun 1960 tentang Perubahan Kitab Undang-Undang Hukum Pidana (selanjutnya disebut UU No. 1 Tahun 1960). UU No. 1 Tahun 1960 merupakan sumber hukum materiil yang diadopsi dari Peraturan Kolonial, Staatsblad Nomor 732 Tahun 1915 tentang Wetboek van Strafrecht voor Nederlandsh-Indie (WvS)/Kitab Undang-Undang Hukum Pidana (selanjutnya disebut WvS). Banyak pihak menilai bahwa UU No. 1 Tahun 1960 yang diadopsi dari WvS sudah tidak relevan dan perlu diperbaharui agar konteks dengan perkembangan zaman. UU No. 1 Tahun 1960 juga memuat aturan yang berbenturan dengan hukum adat dan hukum agama yang tertanam kuat di Indonesia dan diakui sebagai living law. Setelah melalui proses yang panjang dari generasi ke generasi, tibalah saatnya Rancangan Kitab Undang-Undang Hukum Pidana (RKUHP) disahkan pada tahun 2019. Namun, muatan dari pasal-pasalnya dinilai bermasalah oleh banyak pihak,

\footnotetext{
${ }^{9}$ Marc Ancel. (1965). Social Defence: A Modern Approach to Criminal Problems. London: Routledge \& Kegan Paul, hlm. 78.

${ }^{10}$ Administrator. (2019a, 17 Desember 2019). DPR Tetapkan 248 RUU Prolegnas 2020-2024. Sekretariat Jenderal Dewan Perwakilan Rakyat Republik Indonesia. Diakses pada tanggal 12 Desember 2020.
} 
hingga berbagai elemen masyarakat juga menyuarakan untuk dilakukan penundaan pengesahan RKUHP menjadi UU. Penundaan pengesahan RKUHP menjadi UU pun dilaksanakan oleh DPR. Akan tetapi, belum diketahui sampai kapan penundaan ini akan berlangsung.

Dari ratusan pasal yang tercantum dalam RKUHP, terdapat beberapa pasal yang memiliki keunikan jika ditinjau dari aspek perbandingan hukum. Telah banyak penelitian di Indonesia yang membahas RKUHP, baik secara parsial maupun secara menyeluruh, antara lain sebagai berikut.

Penelitian yang berkaitan dengan relevansi dan kontekstualisasi UU No. 1 Tahun 1960, dimana Randy Pradityo menyimpulkan bahwa: ${ }^{11}$

"KUHP dinilai sudah tidak mampu menjawab dan berbagai permasalahan yang terus berkembang dalam kejahatan baru dan tidak konteks lagi dengan dinamika masyarakat saat ini. Sehingga dibutuhkan pembaharuan KUHP yang relevan dan bersumber dari nilai-nilai dasar dan nilai-nilai sosio-filosofis, sosio-politik, dan sosio-kultural dalam yang hidup dalam masyarakat Indonesia."

Penelitian tentang RKUHP yang berkaitan dengan konsep Contempt of Court dari sistem common law, dimana Ruby Hadiarti Johny menyimpulkan bahwa: ${ }^{12}$

"Secara historis, ide dasar Contempt of Court berasal dari ajaran keluarga common law di Inggris. Intinya untuk melindungi lembaga peradilan agar tetap bermartabat dan berwibawa sebagai lembaga yang independen, merdeka, dan mandiri, serta terlepas dari pengaruh-pengaruh pihak lain."

Penelitian tentang RKUHP yang berkaitan dengan Penghinaan terhadap Peradilan, dimana I Made Wirya Darma menyimpulkan bahwa: ${ }^{13}$

"Tindakan yang dilarang dalam konteks contempt of court seharusnya bukan soal isu integritas penyelenggara peradilan, melainkan terhadap tindakan yang menghambat dan mengakibatkan proses persidangan tidak berjalan. Misalnya, intimidasi, ancaman kekerasan, atau tindak kekerasan yang ditujukan kepada hakim terkait dengan penetapan dan putusan hakim. bukanlah soal integritas. mengusulkan agar Contempt of Court Act diatur secara terpisah karena beberapa alasan hukum."

Penelitian tentang RKUHP yang berkaitan dengan perzinaan, dimana Lidya Suryani Widayati menyimpulkan bahwa: ${ }^{14}$

"Revisi pasal perzinaan dalam Rancangan KUHP, tidak hanya karena KUHP merupakan peninggalan kolonial Belanda dan karenanya tidak sesuai

\footnotetext{
${ }^{11}$ Randy Pradityo. (2017). Menuju Pembaharuan Hukum Pidana Indonesia: Suatu Tinjauan Singkat. Jurnal Legislasi Indonesia, Kementerian Hukum dan Hak Asasi Manusia RI, 14(2), hlm. 142.

${ }^{12}$ Ruby Hadiarti Johny. (2009). Contempt of Court (Kajian tentang Ide Dasar dan Implementasinya dalam Hukum Pidana). Dinamika Hukum, Universitas Jenderal Soedirman, 9(2), hlm. 142.

${ }^{13}$ I Made Wirya Darma. (2020). Legal Reform Delik Contempt of Court dalam RUU KUHP 2019. DIH: Jurnal Ilmu Hukum, Universitas 17 Agustus 1945 Surabaya, 16(2), hlm. 199.

${ }^{14}$ Lidya Suryani Widayati. (2009). Revisi Pasal Perzinaan dalam Rancangan KUHP: Studi Masalah Perzinaan di Kota Padang dan Jakarta. Jurnal Hukum Ius Quia Iustum, Universitas Islam Indonesia, 16(3), hlm. 333.
} 
dengan pandangan hidup bangsa Indonesia yang merdeka dan berdaulat, revisi terhadap pasal perzinaan juga karena alasan yang bersifat filosofis, sosiologis dan yuridis dengan berlandaskan kepada norma agama, adat istiadat dan kesusilaan masyarakat. Keinginan atau kesadaran untuk memasukkan nilai-nilai agama maupun adat istiadat dalam KUHP bukanlah suatu yang berlebihan tetapi wajar karena nilai itu adalah ajaran Allah Yang Maha Kuasa (terdapat dalam Mukadimah UUD NRI Tahun 1945) dan atas kesadaran ber-Ketuhanan Yang Maha Esa (Pancasila)."

Penelitian tentang RKUHP yang berkaitan dengan delik santet, dimana Satriadi menyimpulkan bahwa: ${ }^{15}$

"Delik santet tidak merumuskan pembuktian adanya kekuatan gaib karena berada di dimensi lain. Proses pembuktian tidak berdasarkan pada ritual santet tetapi atas tawaran bisa melakukan atau pengakuan bahwa telah melakukan ritual tersebut. Jadi yang dibuktikan adalah hubungan antara tukang santet dengan orang yang menggunakan jasanya, sehingga hubungan tersebut akan dinilai sebagai tindak pidana permufakatan jahat."

Dari beberapa uraian di atas, dapat dipahami bahwa penelitian terdahulu berfokus pada implikasi dari pembaharuan hukum pidana, baik secara parsial maupun secara menyeluruh. Sedangkan penelitian ini berfokus pada aspek perbandingan hukum dalam proses pembentukan hukum. Oleh karenanya, penelitian ini memiliki perbedaan dengan penelitian terdahulu.

Berdasarkan uraian pendahuluan di atas, maka penelitian ini bertujuan untuk menganalisis aspek perbandingan hukum terkait pembentukan pasal penghinaan terhadap peradilan, perzinahan, dan santet dalam RKUHP Indonesia. Diharapkan hasil penelitian ini dapat memberikan manfaat, khususnya pemahaman tentang perbandingan hukum dan peranannya dalam membentuk peraturan perundangundangan berdasarkan perbandingan sistem hukum di Indonesia dengan sistem hukum di berbagai negara lainnya.

\section{METODE}

Metode penelitian dapat diartikan sebagai proses, prinsip-prinsip, dan tata cara untuk memecahkan masalah yang akan dihadapi saat melakukan penelitian. ${ }^{16}$ Penelitian ini menggunakan metode penelitian yuridis normatif dengan spesifikasi bersifat deskriptif.

Penelitian deskriptif adalah penelitian yang menggambarkan sifat-sifat atau karakter individu, keadaan, gejala atau kelompok tertentu. Penelitian deskriptif mempelajari masalah dalam masyarakat dan prosedur yang diterapkan dalam komunitas, termasuk hubungan, aktivitas, sikap, pandangan, proses yang sedang berlangsung,

${ }^{15}$ S. Satriadi. (2020). Delik Santet dalam Konstruksi Rancangan Kitab Undang-Undang Hukum Pidana. Al-Adalah: Jurnal Hukum dan Politik Islam, Institut Agama Islam Negeri Bone, 5(2), hlm. 148.

${ }^{16}$ Jonaedi Efendi \& Johnny Ibrahim. (2016). Metode Penelitian Hukum: Normatif dan Empiris. Jakarta: Kencana Prenada Media Group, hlm. 3. 
dan pengaruhnya terhadap suatu fenomena. ${ }^{17}$

Pendekatan yuridis normatif adalah pendekatan yang dilakukan berdasarkan bahanbahan hukum utama dengan cara menelaah asas-asas hukum, konsep-konsep hukum, dan teori-teori hukum serta peraturan perundang-undangan yang berhubungan dengan penelitian. ${ }^{18}$ Pendekatan ini dikenal pula dengan pendekatan kepustakaan, yang memiliki arti pendekatan dengan mempelajari buku-buku, peraturan perundangundangan, dan dokumen-dokumen lain yang berkaitan dengan penelitian ini.

Adapun metode analisis yang digunakan dalam penelitian ini adalah analisis perbandingan hukum. Perbandingan hukum dilakukan untuk mengetahui persamaan dan perbedaan unsur dari setiap sistem hukum, sehingga dapat menjadi alternatif dalam menyikapi persoalan-persoalan tertentu. Perbandingan hukum juga dilakukan untuk mencari hal-hal yang belum pernah diungkapkan sebelumnya. Olehnya itu dapat dijadikan sebagai sumber bahan hukum dalam membentuk atau memperbaharui peraturan perundang-undangan di masa yang akan datang (futuristic). ${ }^{19}$

\section{HASIL DAN PEMBAHASAN}

\section{A. Sistem Hukum Indonesia}

Salah satu tujuan praktis dari perbandingan hukum adalah untuk kepentingan pembentukan peraturan perundang-undangan. Dalam konteks pembentukan RKUHP, tujuan praktis tersebut dapat diterapkan. Setidaknya ada beberapa pasal dalam RKUHP yang mengadopsi nilai-nilai sistem hukum lainnya. Sebagaimana kita ketahui bersama, secara teori negara Indonesia menganut civil law system sebagai warisan dari Belanda. Namun menurut Esin Orucu, bahwa "tidak ada lagi negara yang murni menganut civil law system atau common law system". ${ }^{20}$

Perpaduan kedua sistem hukum tersebut tidak dapat dihindari. Misalnya, sistem hukum Indonesia yang sudah terpapar unsur-unsur common law, sebagaimana menurut Sudikno Mertokusumo, bahwa: ${ }^{21}$

"Dalam memeriksa dan mengadili suatu perkara, hakim selayaknya berlandaskan pada hukum baik tertulis maupun tidak tertulis. Namun, apabila tidak ada hukumnya hakim dapat menentukan dan membentuk hukumnya."

\footnotetext{
${ }^{17}$ M. Iqbal Hasan. (2002). Pokok-Pokok Materi Metodologi Penelitian dan Aplikasinya. Bogor: Ghalia Indonesia, hlm. 13-14.

${ }^{18}$ Nurul Qamar \& Farah Syah Rezah. (2020). Metode Penelitian Hukum: Doktrinal dan Non-Doktrinal. Makassar: CV. Social Politic Genius (SIGn), hlm. 9.

${ }^{19}$ Siti Anisah. (2009). Studi Komparasi terhadap Perlindungan Kepentingan Kreditor dan Debitor dalam Hukum Kepailitan. Jurnal Hukum Ius Quia Iustum, Universitas Islam Indonesia, 16(Special Issue), hlm. 32.

${ }^{20}$ Esin Orucu. (2008). What is a Mixed Legal System: Exclusion or Expansion? Electronic Journal of Comparative Law, 12(1), hlm. 2.

${ }^{21}$ Sudikno Mertokusumo. (2011). Sejarah Peradilan dan Perundang-Undangannya di Indonesia sejak 1942 dan Apakah Kemanfaatannya Bagi Kita Bangsa Indonesia. Yogyakarta: Universitas Atma Jaya Yogyakarta, hlm. 6.
} 
Pendapat Sudikno ini terinspirasi dengan konsep judge made law negara common law.

Perpaduan antara civil law system dan common law system di Indonesia disertai pula dengan perpaduan antara unsur hukum agama dan hukum adat. Perpaduan hukum agama dalam sistem hukum Indonesia, secara konkrit dapat dilihat pada Pasal 3 ayat (2) Undang-Undang Republik Indonesia Nomor 16 Tahun 2019 tentang Perubahan Atas Undang-Undang Nomor 1 Tahun 1974 tentang Perkawinan, yang mengatur bahwa:

"Pengadilan, dapat memberi izin kepada seorang suami untuk beristeri lebih dari seorang apabila dikehendaki oleh pihak-pihak yang bersangkutan."

Dari ketentuan di atas, poligami tetap mengacu pada ketentuan-ketentuan hukum perkawinan, ${ }^{22}$ dan yang memperkenankan pria memiliki istri lebih dari satu ialah syariat Islam. ${ }^{23}$ Adapun perpaduan hukum adat dalam sistem hukum Indonesia, secara konkret dapat dilihat pada Pasal 51 ayat (2) Undang-Undang Republik Indonesia Nomor 35 Tahun 2008 tentang Penetapan Peraturan Pemerintah Pengganti Undang-Undang Nomor 1 Tahun 2008 tentang Perubahan Atas UndangUndang Nomor 21 Tahun 2001 tentang Otonomi Khusus Bagi Provinsi Papua menjadi Undang-Undang, yang mengatur bahwa "Pengadilan adat disusun menurut ketentuan hukum adat masyarakat hukum adat yang bersangkutan."

Mengenai hukum pidana di Indonesia, sejatinya hanya UU No. 1 Tahun 1960 yang murni menganut civil law system, karena merupakan sumber hukum materiil yang diadopsi dari Peraturan Kolonial. Peraturan perundang-undangan tentang hukum pidana di Indonesia yang diadopsi dari WvS sudah digunakan sejak awal kemerdekaan. Dimulai dari pembentukan Undang-Undang Republik Indonesia Nomor 1 Tahun 1946 tentang Peraturan Hukum Pidana hingga pembentukan UU No. 1 Tahun 1960. Adapun perubahan terakhir secara parsial, yaitu berdasarkan Undang-Undang Republik Indonesia Nomor 27 Tahun 1999 tentang Perubahan Kitab Undang-Undang Hukum Pidana yang Berkaitan dengan Kejahatan Terhadap Keamanan Negara.

UU No. 1 Tahun 1960 yang diadopsi dari WvS dan sudah berlaku cukup lama di Indonesia dinilai oleh beberapa pihak sudah tidak sejalan dengan perkembangan zaman dan perkembangan nilai-nilai dalam masyarakat Indonesia. Atas dasar semangat tersebut, maka disusunlah RKUHP.

Spirit dari suatu pembaharuan hukum pidana melalui RKUHP tidak lepas dari urgensi dan alasan penting terkait masalah nasional, sebagaimana Sudarto

\footnotetext{
${ }^{22}$ Sufirman Rahman, Nurul Qamar, \& Muhammad Kamran. (2020). Efektivitas Pembagian Harta Bersama Pasca Perceraian: Studi Kasus Perkawinan Poligami. SIGn Jurnal Hukum, CV. Social Politic Genius (SIGn), 1(2), hlm. 107.

${ }^{23}$ Choky Ramadhan. (2018). Konvergensi Civil Law dan Common Law di Indonesia dalam Penemuan dan Pembentukan Hukum. Mimbar Hukum, Universitas Gadjah Mada, 30(2), hlm. 215.
} 
mengurai alasan-alasan tersebut, antara lain: ${ }^{24}$

1. Alasan politis yang didasarkan kepada Indonesia sebagai negara merdeka, maka hal yang wajar bila memiliki hukum pidana yang bersifat nasional dengan berdasarkan Pancasila sebagai dasar negara.

2. Alasan sosiologis yang didasarkan kepada pembentukan (pembaharuan) hukum pidana nasional yang bersifat nasional dengan berdasarkan nilai-nilai yang terkandung dalam masyarakat, khususnya kultur masyarakat Indonesia.

3. Alasan praktis yang didasarkan kepada hukum nasional yang berlaku harus dipahami oleh masyarakat yang berada dalam naungan hukum tersebut. Sedangkan dalam konteks UU No. 1 Tahun 1960 yang diadopsi dari WvS, masih banyak menggunakan istilah Belanda sehingga sulit dipahami oleh masyarakat di era saat ini.

Selain dari alasan-alasan yang dikemukakan di atas, juga terdapat alasan dualisme sistem hukum pidana nasional, yaitu sistem hukum pidana yang diatur berdasarkan UU No. 1 Tahun 1960 dan UU yang berkaitan dengan hukum pidana di luar UU No. 1 Tahun 1960. Kondisi inilah yang dianggap oleh pencetus RKUHP akan menimbulkan permasalahan. ${ }^{25}$

Dengan dirumuskannya ketentuan hukum pidana nasional ke dalam RKUHP, maka segala macam ketentuan perundang-undangan pidana akan terunifikasi. ${ }^{26}$ Setelah melalui proses yang panjang selama puluhan tahun, RKUHP yang dinantikan oleh masyarakat Indonesia telah siap dan harusnya sudah disahkan pada Tahun 2019 silam. Namun, muatan dari pasal-pasalnya dinilai bermasalah oleh banyak pihak, sehingga dilakukan penundaan pengesahan RKUHP menjadi UU. Dari 742 Pasal dalam RKUHP, terdapat beberapa pasal yang merupakan perpaduan dari sistem hukum lain, dan pasal-pasal tersebutlah yang akan ditelaah lebih dalam.

\section{B. Perbandingan Muatan Ketentuan antara RKUHP dengan Sistem Hukum Lainnya}

Terdapat beberapa pasal dalam RKUHP yang mengandung unsur perpaduan antara sistem hukum nasional dengan sistem hukum lainnya, antara lain sebagai berikut.

\section{Pasal Penghinaan terhadap Peradilan}

Tindak pidana penghinaan terhadap peradilan atau contempt of court dirumuskan dalam Pasal 302-325 RKUHP. Muatan dari Pasal tersebut merupakan perpaduan dari common law system.

Jika dilihat dari sistem hukumnya, contempt of court berasal dari the common law family atau the Anglo-American/Anglo-Saxon system. Ajaran contempt

\footnotetext{
${ }^{24}$ Barda Nawawi Arief. (1998). Beberapa Aspek Kebijakan Penegakan dan Pengembangan Hukum Pidana. Bandung: PT. Citra Aditya Bakti, hlm. 95.

${ }^{25}$ A. Arsil. (2015). Amandemen KUHP: Alternatif (Lain) Perubahan Hukum Pidana Indonesia. Jakarta: Institute for Criminal Justice Reform, hlm. 4.

${ }^{26}$ Moeljatno. (2008). Asas-Asas Hukum Pidana. Jakarta: PT. Rineka Cipta, hlm. 18.
} 
of court tidak dikenal dalam sistem hukum Indonesia yang menganut civil law system, namun banyak kasusnya yang terjadi di Indonesia. ${ }^{27}$ Penerapan contempt of court dinilai oleh beberapa pihak tidak tepat di diterapkan Indonesia karena berbagai alasan, salah satunya terkait model peradilan pidana. Indonesia merupakan negara yang mengadopsi model non-adversary (inquisitorial). Model inkuisitorial diadopsi oleh negara-negara yang menganut civil law system. ${ }^{28}$ Selain itu, hal tersebut didasarkan pada sejarah Indonesia yang sistem hukumnya mengadopsi sistem hukum Belanda yang menganut civil law system. Model non-adversary dalam peradilan pidana telah memberikan peranan dan wewenang yang begitu besar kepada Hakim. ${ }^{29}$

Adapun peradilan pidana dalam common law system, menggunakan model adversary. Modeladversary dalam peradilan pidana, Hakim tidak diberikan wewenang yang begitu besar. Hakim hanya berperan sebagai fasilitator persidangan, sehingga negara yang menganut common law system, seperti Inggris dan Australia dapat menerapkan contempt of court dalam peradilan pidana.

Oleh karena itu, tidaklah tepat jika contempt of court diterapkan dalam peradilan pidana Indonesia.

\section{Pasal Perzinahan}

Tindak pidana perzinahan dirumuskan dalam Pasal 418 RKUHP. Muatan dari Pasal tersebut merupakan perpaduan dari hukum agama yang ditransformasikan ke dalam sistem hukum Indonesia yang menganut civil law system. Rumusan Pasal 418 RKUHP merupakan salah satu pasal yang paling mendapatkan sorotan karena negara dinilai sudah terlalu jauh masuk ke ranah privat warganya.

Awalnya, berdasarkan Pasal 284 UU No. 1 Tahun 1960, seseorang yang telah terikat perkawinan dapat dikatakan berzina apabila melakukan persetubuhan selain dengan pasangan sahnya. Namun dalam rancangan Pasal 418 RKUHP, seseorang yang tidak terikat perkawinan dapat dikatakan berzina apabila melakukan persetubuhan.

Perlu diperhatikan bahwa norma hukum di masing-masing tempat tidaklah sama. Sehingga norma hukum di Belanda sebagai pembentuk WvS pastilah berbeda dengan norma hukum di Indonesia. Akan tetapi UU No. 1 Tahun 1960 yang diadopsi dari WvS, secara tidak langsung mengharuskan Indonesia untuk mengadopsi norma hukum Belanda dan dijadikan pedoman bagi aparat

\footnotetext{
${ }^{27}$ Ruby Hadiarti Johny. (2009). Op. Cit., hlm. 135.

${ }^{28}$ Andi Hamzah \& R. M. Surachman. (2015). Pre-Trial Justice \& Discretionary Justice dalam KUHAP berbagai Negara. Jakarta: Sinar Grafika, hlm. 9.

${ }^{29}$ Andi Suherman. (2019). Implementasi Independensi Hakim dalam Pelaksanaan Kekuasaan Kehakiman. SIGn Jurnal Hukum, CV. Social Politic Genius (SIGn), 1(1), hlm. 45.
} 
penegak hukum serta masyarakatnya. ${ }^{30}$

Bagi masyarakatyang menganut agama akan menilai bahwa tidak ada perbuatan salah jika berpedoman pada kitab ajaran agamanya. Selain itu, berdasarkan sila pertama Pancasila menganut Ketuhanan Yang Maha Esa sehingga semua masyarakat memiliki kepercayaan di hadapan negara Indonesia. Oleh karena itu norma hukum di Indonesia sangat dipengaruhi oleh sistem hukum agama. Lebih lanjut, apabila terdapat suatu penyimpangan dari ajaran agama, sedangkan penyimpangan tersebut belum masuk dalam peraturan perundangundangan, maka akan terjadi tindakan persekusi atau main hakim sendiri. Faktanya, tindakan persekusi atau main hakim sendiri sudah menjadi hal yang biasa disaksikan belakangan ini.

Dari uraian di atas, dapat dinilai bahwa terdapat perbandingan antara Pasal 418 RKUHP yang mengadopsi hukum agama dengan Pasal 284 UU No. 1 Tahun 1960 yang murni menganut civil law system.

Di Indonesia, norma hukum agama tidak perlu berbenturan dengan civil law system yang kita gunakan saat ini. Namun demikian, dapat digunakan sebagai sarana pembaharuan hukum di Indonesia, khususnya masalah perzinahan. Pasal 418 RKUHP berkaitan dengan perzinaan harusnya dinilai sebagai salah satu bentuk pembaharuan dan pengakuan dari negara pada living law yang tumbuh di masyarakat.

\section{Pasal Santet}

Tindak pidana delik santet dirumuskan dalam Pasal 252 RKUHP. Muatan dari Pasal tersebut merupakan perpaduan antara sistem hukum adat dengan sistem hukum agama yang berusaha diterapkan ke dalam sistem hukum Indonesia.

Definisi dari santet adalah perbuatan gaib yang dilakukan dengan pesona guna-guna, mantra, jimat, dan mengikut sertakan syaitan, sehingga dapat memberikan pengaruh terhadap badan, hati, atau pikiran yang disihir tanpa harus menyentuhnya. ${ }^{31}$ Setiap daerah di Indonesia memiliki istilah sendiri dalam menyebutkan maksud dari santet. Istilah santet umumnya dikenal di Jawa Timur. Sedangkan istilah lainnya yaitu teluh di Jawa Barat, doti di Sulawesi Selatan, tenung di Jawa Tengah, pulung di Kalimantan Barat dan sebagainya. ${ }^{32}$ Aturan mengenai santet atau sihir telah diterapkan oleh Negara Arab Saudi yang menganut hukum Syariah Islam dengan berdasarkan pada pengamalan Nabi Muhammad SAW, juga didasari oleh pemahaman sahabat nabi terhadap

\footnotetext{
${ }^{30}$ Hasan Basri. (2021). Perlindungan Hukum terhadap Pelaku Tindak Pidana berdasarkan Sistem Peradilan Pidana Indonesia. SIGn Jurnal Hukum, CV. Social Politic Genius (SIGn), 2(2), hlm. 106.

${ }^{31}$ J. Jamhuri \& Zuhaini Nopitasari. (2018). Penyelesaian Pelaku Santet dengan Hukum Adat Ditinjau Melalui Hukum Islam di Kecamatan Gajah Putih. Legitimasi: Jurnal Hukum Pidana dan Politik Hukum, Universitas Islam Negeri Ar-Raniry Banda Aceh, 7(1), hlm. 91.

${ }^{32}$ S. Satriadi. (2020). Op. Cit., hlm. 137.
} 
Al-Quran dan Hadits. ${ }^{33}$ Di negara yang menganut sistem hukum agama Islam seperti Arab Saudi, pengakuan terhadap hal gaib dan mistis begitu kuat sehingga pemberantasannya masuk dalam sistem hukum negara tersebut. Keseriusan Arab Saudi untuk memberantas praktik santet telah dibuktikan, dimana pada tahun 2009 membentuk "Anti-Witchcraft Unit" sebagai langkah untuk memberantas praktik sihir. ${ }^{34}$

Dari uraian di atas dan berdasarkan perbandingan hukum antara penerapan pemberantasan praktik santet di Arab Saudi dengan rumusan Pasal 252 RKUHP, dapat dikatakan bahwa Indonesia telah mengadopsi nilai-nilai hukum agama Islam sebagai pembaharuan hukum pidana dalam RKUHP.

Adapun negara-negara yang tidak menganut sistem hukum agama tapi memiliki ketentuan hukum tentang ilmu sihir, antara lain Negara Papua Nugini dan Negara Zambia.

Perlu diketahui bahwa Zambia merupakan negara yang menganut common law system. ${ }^{35}$ Nama resmi untuk peraturan perundang-undangan tentang sihir di Zambia disebut "Chapter 90 The Witchcraft Act". Selanjutnya, Papua Nugini merupakan negara yang juga menganut common law system. Nama resmi untuk peraturan perundang-undangan tentang sihir di Papua Nugini disebut "Sorcery Act 1971".

Papua Nugini dan Zambia membentuk peraturan perundang-undangan tentang sihir bukan karena atas dasar agama seperti Arab Saudi, melainkan karena hukum adat di kedua negara yang sangat kuat. Selain itu, adat di kedua negara tersebut sangat mempercayai hal-hal mistis dan keberadaan penyihir.

Indonesia, Zambia, dan Papua Nugini memiliki kesamaan dimana di setiap daerahnya memiliki hukum adat yang diyakini oleh masyarakatnya sebagai living law. Karakteristik dari hukum adat Indonesia adalah komunal, kontan, dan religion magis. Religion magis sendiri dapat diartikan bahwa percaya adanya kekuatan gaib. ${ }^{36}$

Perumusan RKUHP yang berkaitan dengan delik santet, merupakan perbandingan hukum dari hukum agama, hukum adat dan diimplementasikan ke dalam civil law system di Indonesia.

Peran perbandingan hukum dalam pembaharuan hukum pidana di Indonesia sangat penting. Hal ini dikarenakan dengan melakukan perbandingan hukum

\footnotetext{
${ }^{33}$ Agustina Nurhayati. (2014). Politik Hukum (Legislasi) Hukum Keluarga di Saudi Arabia. Ijtimaiyya: Jurnal Pengembangan Masyarakat Islam, Universitas Islam Negeri Raden Intan, 7(1), hlm. 67.

${ }^{34}$ David E. Miller. (2011, 20 Juli). Saudi Arabia's 'Anti-Witchcraft Unit' Breaks Another Spell. The Jerusalem Post. Diakses pada tanggal 9 April 2020.

${ }^{35}$ Administrator. (2019b, 8 Oktober). Zambia. Kedutaan Besar Republik Indonesia di Harare, Zimbabwe. Diakses pada tanggal 9 April 2020.

${ }^{36}$ Bewa Ragawino. (2008). Pengantar dan Asas-Asas Hukum Adat Indonesia. Bandung: Fakultas Ilmu Sosial dan Ilmu Politik, Universitas Padjadjaran, hlm. 10.
} 
dengan sistem hukum negara lain, kita dapat menilai apakah penerapan peraturan perundang-undangan tersebut sudah tepat. Misalnya, ajaran contempt of court yang diterapkan di negara-negara yang menganut common law system, apakah sudah tepat jika diterapkan pada Indonesia yang dimana menganut civil law system. Selain itu, perbandingan hukum dengan sistem hukum agama dan sistem hukum adat yang diyakini oleh masyarakatnya sebagai living law juga dapat dilakukan sebagai pembaharuan hukum pidana.

Peran perbandingan hukum akan terus digunakan untuk kedepannya sebagai alat guna memperbaharui peraturan perundang-undangan yang ada di setiap negara agar sesuai dengan kondisi masyarakat saat ini.

\section{KESIMPULAN DAN SARAN}

Berdasarkan uraian hasil dan pembahasan, maka dapatdisimpulkan bahwa perbandingan hukum merupakan suatu kegiatan yang dilakukan untuk membandingkan sistemsistem hukum yang ada di berbagai negara. Sebagaimana kita ketahui bersama bahwa secara teori, Indonesia menganut civil law system sebagai warisan dari Belanda. Akan tetapi, tidak ada lagi negara yang murni menganut civil law system atau common law system. Perpaduan antara civil law system dan common law system di Indonesia disertai pula dengan perpaduan antara unsur hukum agama dan hukum adat. Hal ini dapat diketahui dari aspek perbandingan hukum terkait pembentukan pasal penghinaan terhadap peradilan, perzinahan, dan santet dalam RKUHP Indonesia. Tindak pidana penghinaan terhadap peradilan atau contempt of court dirumuskan dalam Pasal 302-325 RKUHP, dimana muatan dari Pasal tersebut merupakan perpaduan dari common law system. Tindak pidana perzinahan dirumuskan dalam Pasal 418 RKUHP, dimana muatan dari Pasal tersebut merupakan perpaduan dari hukum agama yang ditransformasikan ke dalam sistem hukum Indonesia yang menganut civil law system. Tindak pidana delik santet dirumuskan dalam Pasal 252 RKUHP, dimana muatan dari Pasal tersebut merupakan perpaduan antara sistem hukum adat dengan sistem hukum agama yang berusaha diterapkan ke dalam sistem hukum Indonesia. Dengan dasar kesimpulan tersebut, disarankan agar peran perbandingan hukum dalam menelaah proses pembaharuan hukum harus terus dilakukan, sehingga sistem hukum di Indonesia terus bergerak ke arah yang lebih baik. Perbandingan hukum juga dapat mengevaluasi sistem hukum yang diberlakukan, bagaimana penerapannya dan apakah sesuai dengan sistem hukum di Indonesia.

\section{REFERENSI}

A. Arsil. (2015). Amandemen KUHP: Alternatif (Lain) Perubahan Hukum Pidana Indonesia. Jakarta: Institute for Criminal Justice Reform.

Ach. Dlofirul Anam. (2015). "Studi Komparasi antara Konsep Hak Jaminan Resi Gudang Menurut Undang-Undang No. 9 Tahun 2011 dengan Konsep Rahn (Gadai) dalam Hukum Islam". Skripsi. Fakultas Syariah, Universitas Islam Negeri Maulana Malik Ibrahim, Malang. 
Administrator. (2019a, 17 Desember 2019). DPR Tetapkan 248 RUU Prolegnas 2020-2024. Sekretariat Jenderal Dewan Perwakilan Rakyat Republik Indonesia. Diakses dari https://www.dpr.go.id/berita/detail/id/26971/t/ DPR+Tetapkan+248+RUU+Prolegnas+2020-2024, pada tanggal 12 Desember 2020.

Administrator. (2019b, 8 Oktober). Zambia. Kedutaan Besar Republik Indonesia di Harare, Zimbabwe. Diakses dari https://kemlu.go.id/harare/id/read/ zambia/2728/etc-menu, pada tanggal 9 April 2020.

Agustina Nurhayati. (2014). Politik Hukum (Legislasi) Hukum Keluarga di Saudi Arabia. Ijtimaiyya: Jurnal Pengembangan Masyarakat Islam, Universitas Islam Negeri Raden Intan, 7(1), hlm. 67-82.

Andi Hamzah \& R. M. Surachman. (2015). Pre-Trial Justice \& Discretionary Justice dalam KUHAP berbagai Negara. Jakarta: Sinar Grafika.

Andi Suherman. (2019). Implementasi Independensi Hakim dalam Pelaksanaan Kekuasaan Kehakiman. SIGn Jurnal Hukum, CV. Social Politic Genius (SIGn), 1(1), hlm. 42-51.

Barda Nawawi Arief. (1990). Perbandingan Hukum Pidana. Jakarta: Rajawali Pers.

Barda Nawawi Arief. (1998). Beberapa Aspek Kebijakan Penegakan dan Pengembangan Hukum Pidana. Bandung: PT. Citra Aditya Bakti.

Bewa Ragawino. (2008). Pengantar dan Asas-Asas Hukum Adat Indonesia. Bandung: Fakultas Ilmu Sosial dan Ilmu Politik, Universitas Padjadjaran.

Choky Ramadhan. (2018). Konvergensi Civil Law dan Common Law di Indonesia dalam Penemuan dan Pembentukan Hukum. Mimbar Hukum, Universitas Gadjah Mada, 30(2), hlm. 213-229. doi: https://doi.org/10.22146/jmh.31169

David E. Miller. (2011, 20 Juli). Saudi Arabia's 'Anti-Witchcraft Unit' Breaks Another Spell. The Jerusalem Post. Diakses dari https://www.jpost.com/middle-east/ saudi-arabias-anti-witchcraft-unit-breaks-another-spell, pada tanggal 9 April 2020.

Esin Orucu. (2008). What is a Mixed Legal System: Exclusion or Expansion? Electronic Journal of Comparative Law, 12(1), hlm. 1-18.

Hasan Basri. (2021). Perlindungan Hukum terhadap Pelaku Tindak Pidana berdasarkan Sistem Peradilan Pidana Indonesia. SIGn Jurnal Hukum, CV. Social Politic Genius (SIGn), 2(2), hlm. 104-121. doi: https://doi.org/10.37276/sjh.v2i2.90

I Made Wirya Darma. (2020). Legal Reform Delik Contempt of Court dalam RUU KUHP 2019. DIH: Jurnal Ilmu Hukum, Universitas 17 Agustus 1945 Surabaya, 16(2), hlm. 190-200. doi: https://doi.org/10.30996/dih.v16i2.3314

Independent State of Papua New Guinea Chapter 274 on The Sorcery Act 1971.

J. Jamhuri \& Zuhaini Nopitasari. (2018). Penyelesaian Pelaku Santet dengan Hukum Adat Ditinjau Melalui Hukum Islam di Kecamatan Gajah Putih. Legitimasi: Jurnal Hukum Pidana dan Politik Hukum, Universitas Islam Negeri Ar-Raniry Banda Aceh, 7(1), hlm. 91-107. doi: http://dx.doi.org/10.22373/legitimasi.v7i1.3966 
John Henry Merryman \& Rogelio Pérez-Perdomo. (2007). The Civil Law Tradition: An Introduction to the Legal Systems of Europe and Latin America. California: Stanford University Press.

Jonaedi Efendi \& Johnny Ibrahim. (2016). Metode Penelitian Hukum: Normatif dan Empiris. Jakarta: Kencana Prenada Media Group.

Lidya Suryani Widayati. (2009). Revisi Pasal Perzinaan dalam Rancangan KUHP: Studi Masalah Perzinaan di Kota Padang dan Jakarta. Jurnal Hukum Ius Quia Iustum, Universitas Islam Indonesia, 16(3), hlm. 311-336. doi: https://doi.org/10.20885/ iustum.vol16.iss3.art2

M. Iqbal Hasan. (2002). Pokok-Pokok Materi Metodologi Penelitian dan Aplikasinya. Bogor: Ghalia Indonesia.

Marc Ancel. (1965). Social Defence: A Modern Approach to Criminal Problems. London: Routledge \& Kegan Paul.

Moeljatno. (2008). Asas-Asas Hukum Pidana. Jakarta: PT. Rineka Cipta.

Nurul Qamar \& Farah Syah Rezah. (2020). Metode Penelitian Hukum: Doktrinal dan Non-Doktrinal. Makassar: CV. Social Politic Genius (SIGn).

Peraturan Kolonial, Staatsblad Nomor 732 Tahun 1915 tentang Wetboek van Strafrecht voor Nederlandsh-Indie (WvS)/Kitab Undang-Undang Hukum Pidana.

Peraturan Pemerintah Pengganti Undang-Undang Republik Indonesia Nomor 1 Tahun 2008 tentang Perubahan Atas Undang-Undang Nomor 21 Tahun 2001 tentang Otonomi Khusus Bagi Provinsi Papua Tahun 2001 tentang Otonomi Khusus Bagi Provinsi Papua menjadi Undang-Undang. (Lembaran Negara Republik Indonesia Tahun 2008 Nomor 57. Tambahan Lembaran Negara Republik Indonesia Nomor 4842).

Randy Pradityo. (2017). Menuju Pembaharuan Hukum Pidana Indonesia: Suatu Tinjauan Singkat. Jurnal Legislasi Indonesia, Kementerian Hukum dan Hak Asasi Manusia RI, 14(2), hlm. 137-144.

René David \& John E. C. Brierley. (1978). Major Legal Systems in the World Today: An Introduction to the Comparative Study of Law. New York: Free Press.

Romli Atmasasmita. (1996). Perbandingan Hukum Pidana. Bandung: CV. Mandar Maju.

Ruby Hadiarti Johny. (2009). Contempt of Court (Kajian tentang Ide Dasar dan Implementasinya dalam Hukum Pidana). Dinamika Hukum, Universitas Jenderal Soedirman, 9(2), hlm. 135-143. doi: http://dx.doi.org/10.20884/1. jdh.2009.9.2.221

S. Satriadi. (2020). Delik Santet dalam Konstruksi Rancangan Kitab Undang-Undang Hukum Pidana. Al-Adalah: Jurnal Hukum dan Politik Islam, Institut Agama Islam Negeri Bone, 5(2), hlm. 135-149. doi: http://dx.doi.org/10.35673/ajmpi.v5i2.807

Siti Anisah. (2009). Studi Komparasi terhadap Perlindungan Kepentingan Kreditor dan Debitor dalam Hukum Kepailitan. Jurnal Hukum Ius Quia Iustum, Universitas Islam Indonesia, 16(Special Issue), hlm. 30-50. 
Sudikno Mertokusumo. (2011). Sejarah Peradilan dan Perundang-Undangannya di Indonesia sejak 1942 dan Apakah Kemanfaatannya Bagi Kita Bangsa Indonesia. Yogyakarta: Universitas Atma Jaya Yogyakarta.

Sufirman Rahman, Nurul Qamar, \& Muhammad Kamran. (2020). Efektivitas Pembagian Harta Bersama Pasca Perceraian: Studi Kasus Perkawinan Poligami. SIGn Jurnal Hukum, CV. Social Politic Genius (SIGn), 1(2), hlm. 104-118. doi: https://doi. org/10.37276/sjh.v1i2.60

Sunarjati Hartono. (1986). Kapita Selekta Perbandingan Hukum. Bandung: PT. Alumni.

The Laws of Zambia Number 13 of 1994 on Chapter 90 The Witchcraft Act.

Undang-Undang Dasar Negara Republik Indonesia Tahun 1945.

Undang-Undang Republik Indonesia Nomor 1 Tahun 1946 tentang Peraturan Hukum Pidana.

Undang-Undang Republik Indonesia Nomor 1 Tahun 1960 tentang Perubahan Kitab Undang-Undang Hukum Pidana. (Lembaran Negara Republik Indonesia Tahun 1960 Nomor 1. Tambahan Lembaran Negara Republik Indonesia Nomor 1921).

Undang-Undang Republik Indonesia Nomor 1 Tahun 1974 tentang Perkawinan. (Lembaran Negara Republik Indonesia Tahun 1974 Nomor 1. Tambahan Lembaran Negara Republik Indonesia Nomor 3019).

Undang-Undang Republik Indonesia Nomor 27 Tahun 1999 tentang Perubahan Kitab Undang-Undang Hukum Pidana yang Berkaitan dengan Kejahatan Terhadap Keamanan Negara. (Lembaran Negara Republik Indonesia Tahun 1999 Nomor 74. Tambahan Lembaran Negara Republik Indonesia Nomor 3850).

Undang-Undang Republik Indonesia Nomor 21 Tahun 2001 tentang Otonomi Khusus Bagi Provinsi Papua. (Lembaran Negara Republik Indonesia Tahun 2001 Nomor 135. Tambahan Lembaran Negara Republik Indonesia Nomor 4151).

Undang-Undang Republik Indonesia Nomor 35 Tahun 2008 tentang Penetapan Peraturan Pemerintah Pengganti Undang-Undang Nomor 1 Tahun 2008 tentang Perubahan Atas Undang-Undang Nomor 21 Tahun 2001 tentang Otonomi Khusus Bagi Provinsi Papua menjadi Undang-Undang. (Lembaran Negara Republik Indonesia Tahun 2008 Nomor 112. Tambahan Lembaran Negara Republik Indonesia Nomor 4884).

Undang-Undang Republik Indonesia Nomor 16 Tahun 2019 tentang Perubahan Atas Undang-Undang Nomor 1 Tahun 1974 tentang Perkawinan. (Lembaran Negara Republik Indonesia Tahun 2019 Nomor 186. Tambahan Lembaran Negara Republik Indonesia Nomor 6401).

\footnotetext{
Farrel Alanda Fitrah. (2021). Perbandingan Hukum terkait Pembentukan Pasal ' Penghinaan terhadap Peradilan, Perzinahan, dan Santet dalam RKUHP Indonesia. I I SIGn Jurnal Hukum, CV. Social Politic Genius (SIGn), 2(2), hlm. 122-137. doi: https:// ' I doi.org/10.37276/sjh.v2i2.93
} 